\title{
GABAergic Synchronization in Epilepsy
}

\author{
Roustem Khazipov ${ }^{1,2,3}$ \\ ${ }^{1}$ INMED-INSERM U901, 13273 Marseille Cedex 09, France \\ ${ }^{2}$ Aix-Marseille University, 13273 Marseille Cedex 09, France \\ ${ }^{3}$ Laboratory of Neurobiology, Kazan Federal University, 420008 Kazan, Russia \\ Correspondence: roustem.khazipov@inserm.fr
}

$\gamma$-Aminobutyric acid (GABA) is the main inhibitory neurotransmitter in the cerebral cortex. GABAergic inhibition enables synchronization of activity in cortical networks, and contributes to generation of variety of brain activity patterns. In relation to epilepsy, GABAergic inhibition has been traditionally viewed as the main mechanism counterbalancing glutamatergic excitation and preventing hypersynchronous neuronal discharges. Indeed, deficits in GABAergic functions most commonly result in a hyperexcitable epileptic state, and many of the currently used antiepileptic drugs act through enhancement of GABAergic functions. However, a number of observations show that some epileptiform activity patterns involve synchronization by GABAergic mechanisms. These include two main categories that will be reviewed here: (1) synchronization of epileptiform oscillations based on GABAergic inhibition, and (2) epileptiform events driven by depolarizing and excitatory GABA. The conclusion is reached that GABAergic control of spike timing, either through inhibition or excitation under certain conditions, may work as a powerful synchronizing mechanism during epilepsy.

$\gamma$ - mino butyric acid (GABA) is the main inhibitory neurotransmitter in the cerebral cortex. GABAergic inhibition enables synchronization of activity in neuronal networks, and contributes to the generation of a variety of brain-activity patterns, sets the temporal window for integration of excitatory inputs, and controls synaptic plasticity (Freund and Buzsaki 1996; Buzsaki 2006; Klausberger and Somogyi 2008). GABAergic inhibition has long been considered as the main brake in the neuronal networks that prevents generation and spread of paroxysmal activities (Trevelyan and Schevon 2013). Considerable evidence indicates that inherent or acquired deficiency in GABAergic functions result in epilepsy (Lerche et al.
2013). Blockade of GABAergic inhibition in healthy brain results in acute epileptic discharges, and blockers of GABA receptors, including penicillin, pentylenetetrazole (PTZ), and bicuculline, are widely used as experimental epilepsy models (Curtis et al. 1970; Connors 1984; Miles and Wong 1987). In addition, drugs enhancing GABAergic inhibition most commonly alleviate seizures. These include positive allosteric modulators of $\mathrm{GABA}_{\mathrm{A}}$ receptors, benzodiazepines and barbiturates, and drugs that inhibit GABA uptake, such as tiagabine, or GABA degradation, such as vigabatrin. However, GABAergic involvement in epileptic phenomena may be more complex than one could assume from a simple look at GABA as an endogenous anti-

Editors: Gregory L. Holmes and Jeffrey L. Noebels

Additional Perspectives on Epilepsy: The Biology of a Spectrum Disorder available at www.perspectivesinmedicine.org

Copyright (C) 2016 Cold Spring Harbor Laboratory Press; all rights reserved; doi: 10.1101/cshperspect.a022764

Cite this article as Cold Spring Harb Perspect Med 2016;6:a022764 
convulsive agent. Actually, GABAergic interneurons may act as network synchronizers during certain types of epileptiform activities that will be discussed in this review.

\section{SYNCHRONIZATION OF EPILEPTIFORM ACTIVITIES BY INHIBITORY GABA}

Seizure is a result of hypersynchronous neuronal discharges, during which summation of nearly synchronously occurring action potentials (APs) and postsynaptic currents gives rise to large amplitude epileptic electroencephalography (EEG) patterns. Because synchronous GABAergic inhibition is a powerful mechanism of neuronal synchronization during generation of physiological activity patterns, one could assume that synchronization by inhibition may also occur during generation of paroxysmal discharges. Several examples indicate that the mechanism of synchronization via inhibition indeed operates during generation of some types of epileptiform activities.

Application of kainic acid to the hippocampus in rats in vivo evokes large population spikes in CA3 regions with a very high probability of recruitment of individual CA3 pyramidal cells during each population spike (Fig. 1) (Khazipov and Holmes 2003). These population spikes regularly occur at $30-40 \mathrm{~Hz}$ ( $\gamma$ frequency band) through the entire period of kainic acid application. Whole-cell recordings of synaptic currents and pharmacological analysis revealed a pivotal role for inhibitory GABA in neuronal synchronization and generation of these rhythmically occurring population spikes and surprisingly little participation of glutamatergic excitatory currents. In this model, interspike intervals are primarily determined by duration of GABAergic inhibition similarly to physiological $\gamma$ oscillations. Kainate and some other agents (e.g., carbachol) also evoke network oscillations at $\gamma$ frequency in hippocampal slices in vitro; these are mechanistically similar to $\gamma$ rhythmic epileptic activity observed in vivo but they are smaller in amplitude, less synchronized, and resemble more physiological $\gamma$ oscillations (Mann and Paulsen 2007; Gulyas et al. 2010; Whittington et al. 2011). These findings lead to a conclusion that fundamental mechanisms of neuronal synchronization at $\gamma$ frequency by virtue of synchronous GABAergic inhibition may operate not only during generation of physiological $\gamma$ oscillations but also during epileptiform $\gamma$ activity with a quantitative difference in the level of neuronal synchrony, which is much higher in the epileptic case.

Interneurons can synchronize neuronal networks acting not only via $\mathrm{GABA}_{\mathrm{A}}$, but also via $\mathrm{GABA}_{\mathrm{B}}$ receptors. Activation of postsynaptic potassium conductance by $\mathrm{GABA}_{\mathrm{B}}$ receptors involves G-protein-mediated cascades and, therefore, the $\mathrm{GABA}_{\mathrm{B}}$ receptor-mediated inhibitory postsynaptic potentials (IPSPs) are slow, lasting for hundreds of milliseconds. One could expect, from the slow kinetics of $\mathrm{GABA}_{\mathrm{B}}$ IPSPs, a propensity to synchronize, via inhibition, neuronal networks at lower frequency than by the $\mathrm{GABA}_{\mathrm{A}}$ receptor-mediated inhibition. This is indeed the case of the disinhibited thalamic network generating slow $(\sim 3 \mathrm{~Hz})$ rhythmic population activity resembling what occurs during an absence seizure (von Krosigk et al. 1993). Under physiological conditions, thalamic slices of the ferret lateral geniculate nucleus generate spontaneous spindle waves by rebound burst firing in glutamatergic relay cells. This rebound firing results from $\mathrm{GABA}_{\mathrm{A}}$ receptormediated IPSPs arriving from the perigeniculate nucleus, the interneurons that are activated by burst firing in relay neurons (Steriade et al. 1993). Pharmacological suppression of the $\mathrm{GABA}_{\mathrm{A}}$ receptor-mediated inhibition markedly boosts the discharge of interneurons and enhances $\mathrm{GABA}_{\mathrm{B}}$ receptor-mediated IPSPs in relay cells and subsequently generates slowed and rhythmic seizure-like population activity at $\sim 3 \mathrm{~Hz}$, which was completely abolished after further pharmacological blockage of $\mathrm{GABA}_{\mathrm{B}}$ receptors (von Krosigk et al. 1993).

Inhibitory synchronization of cortical networks has been suggested as a mechanism underlying seizures in autosomal dominant nocturnal frontal lobe epilepsy (ADNFLE), which is associated with selected mutations in the $\alpha 4$ or $\beta 2$ neuronal nicotinic acetylcholine receptor subunit genes (Klaassen et al. 2006). ADNFLE mutant mice showed persistent, abnormal cor- 
A Field CA3 S. Pyr.

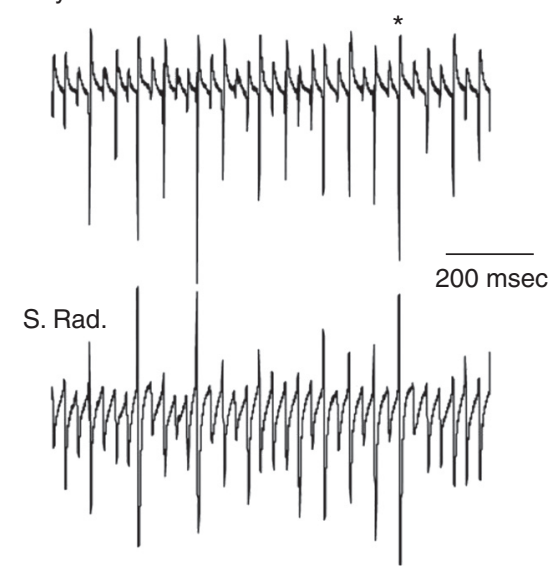

B
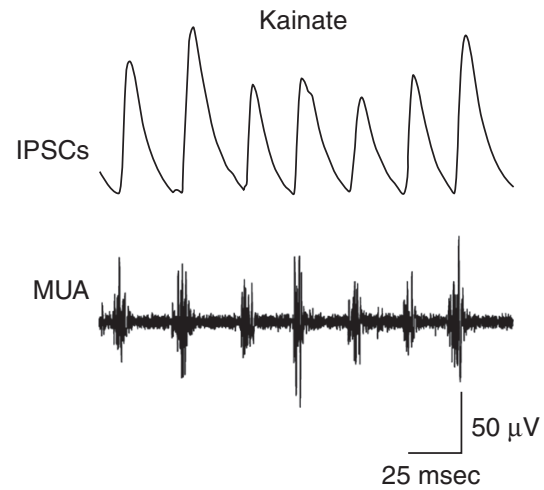

D

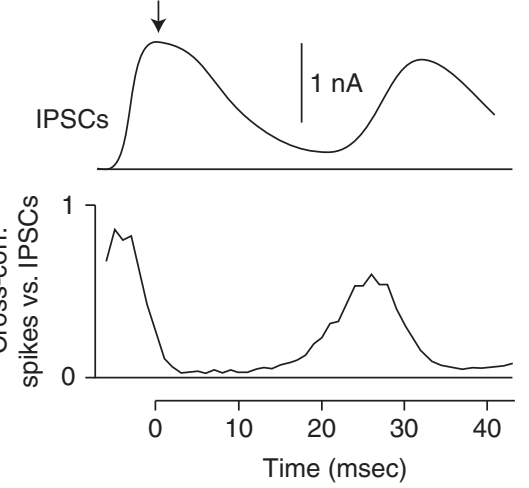

Kainate $(1 \mu \mathrm{m})$

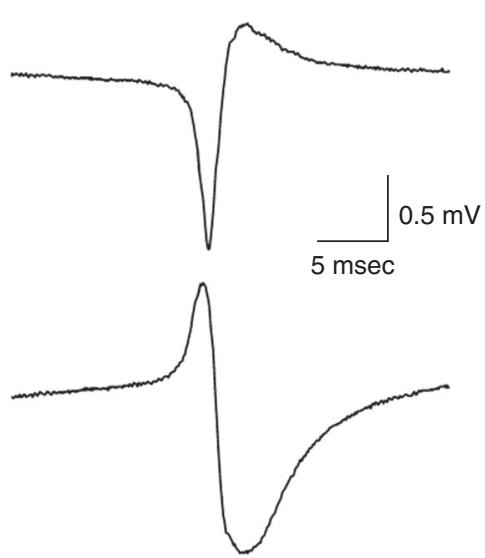

C
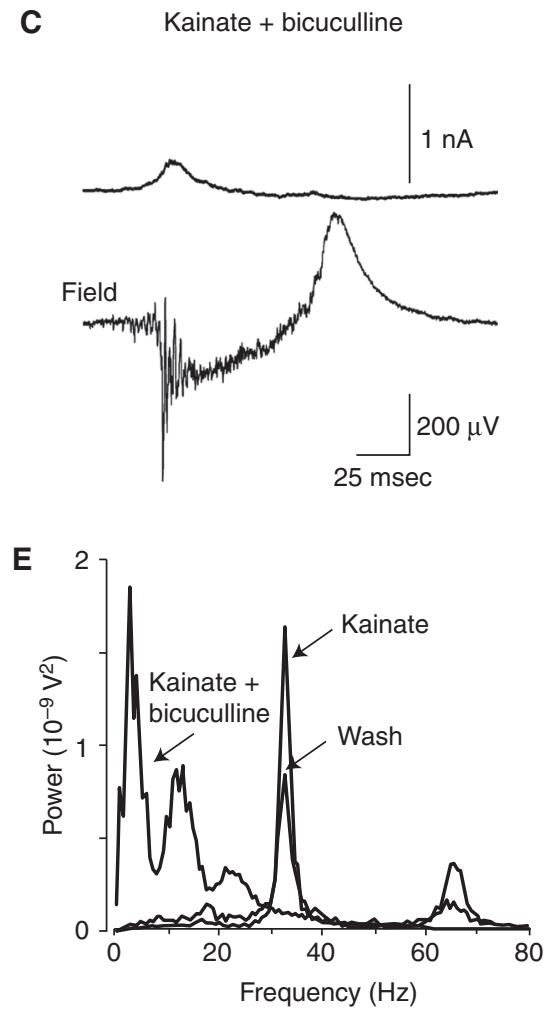

Figure 1. GABAergic synchronization of kainate-induced epileptiform oscillations in rat hippocampus in vivo. (A) Extracellular field potential recordings in the pyramidal cell layer (S. Pyr., top trace) and stratum radiatum (S. Rad., bottom trace) of the CA3a subfield of hippocampus in the presence of $1 \mu \mathrm{m}$ kainate in the perfusing solution. On the right, the population spike marked by an asterisk is shown on an expanded time scale. $(B)$ $\mathrm{GABA}_{\mathrm{A}}$ inhibitory postsynaptic currents (IPSCs) were recorded from a putative CA3a pyramidal cell in a wholecell mode at a holding potential $0 \mathrm{mV}$. Bottom trace represents concomitant recordings of multiple unity activity (MUA) in the CA3 pyramidal cell layer (high pass, $500 \mathrm{~Hz}$ ). (C) Average collective IPSC is plotted above the cross-correlation of the times of spikes recorded with an extracellular electrode against the times of the peak of collective IPSCs (>1000 cycles). (Legend continues on following page.) 
R. Khazipov

tical electroencephalograms with prominent $\delta$ and $\theta$ frequencies, showed frequent spontaneous seizures, and showed an increased sensitivity to the proconvulsant action of nicotine. Relative to wild-type (wt), electrophysiological recordings from ADNFLE mouse layer II/ III cortical pyramidal cells revealed a $>20$-fold increase in nicotine-evoked inhibitory postsynaptic currents (IPSCs) with no effect on excitatory postsynaptic currents. Intraperitoneal (i.p.) injection of a subthreshold dose of the $\mathrm{GABA}_{\mathrm{A}}$ receptors antagonist picrotoxin (PTX) reduced cortical electroencephalogram $\delta$ power and transiently inhibited spontaneous seizure activity in ADNFLE mutant mice (Fig. 2). It has been suggested that the mechanism underlying ADNFLE seizures may involve inhibitory synchronization of cortical networks via activation of mutant $\alpha 4$-containing nicotinic acetylcholine receptors located on the presynaptic terminals and somatodendritic compartments of cortical GABAergic interneurons.

GABAergic inhibition not only participates in network synchronization but may also contribute to the generation of extracellular local field potentials (LFPs). Although the driving force $\left(D F_{\mathrm{GABA}}\right)$ acting on currents through $\mathrm{GABA}_{\mathrm{A}}$ channels $\left(D F_{\mathrm{GABA}}=E_{\mathrm{GABA}}-\right.$ $E_{m}$, where $E_{\mathrm{GABA}}$ is the reversal potential of the currents through $\mathrm{GABA}_{\mathrm{A}}$ channels and $E_{m}$ is the resting membrane potential) is relatively small, in the range of few millivolts, there are several factors that can make GABAergic current an important source for the outwardly directed transmembrane currents that are seen as active sources during extracellular recordings of the LFP. Actually, firing of a single interneuron generates the source at the location of its densely packed and numerous synapses on the target neurons (Glickfeld et al. 2009; Bazelot et al. 2010). Thus, firing of perisomatic-projecting basket cells evokes $\mathrm{GABA}_{\mathrm{A}}$ receptor-mediated

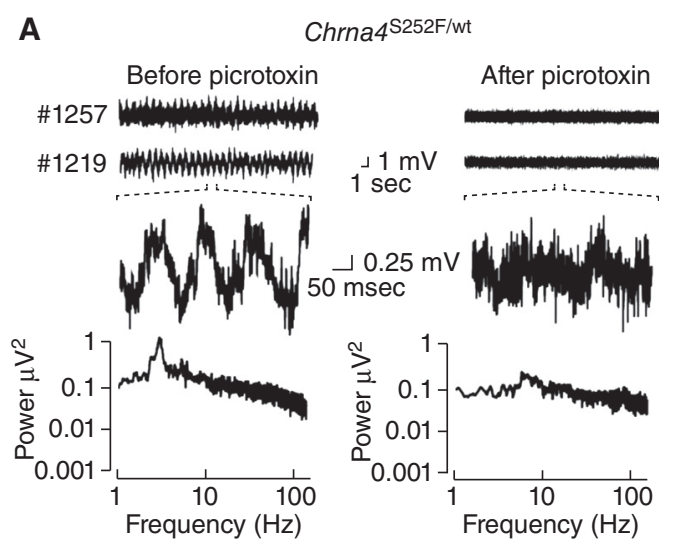

B

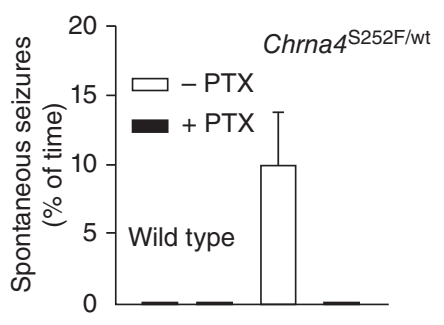

Figure 2. Seizures in autosomal dominant nocturnal frontal lobe epilepsy involve inhibitory synchronization of cortical networks. (A) Chrna4S252F/wildtype (wt) mice, a model of human autosomal dominant nocturnal frontal lobe epilepsy (ADNFLE), have abnormal cortical electroencephalographs (EEGs) with persistent $\delta(0.5-4 \mathrm{~Hz})$ activity, which is decreased by low-dose picrotoxin (PTX). Bottom, FFT analysis shows the decrease in $\delta$ activity in Chrna4 S252F/wt mice after treatment with PTX. (B) Low-dose PTX completely eliminates spontaneous seizures in Chrna4 S252F/wt mice during the $60 \mathrm{~min}$ immediately after PTX injection. (Panels based on data from Klaassen et al. 2006.)

positive unitary IPSCs (uIPSCs) during extracellular recordings from the pyramidal cell layer, where the axons of basket cells establish synaptic connections on pyramidal cell soma. These uIPSCs have the time course and show pairpulse depression during repetitive stimulation

Figure 1. (Continued) Note that phasic inhibition of neuronal firing coincides with the time course of the $\mathrm{GABA}_{\mathrm{A}}$-mediated currents. $(D) \mathrm{GABA}_{\mathrm{A}}$ receptor antagonist bicuculline $(20 \mu \mathrm{M})$ suppresses kainate-induced oscillations and induces interictal-like and ictal-like activities. Recordings from the same neuron shown in $B$. $(E)$ Power spectra of extracellular field potential recordings in the presence of kainate, after addition of bicuculline and after 15 min of a wash of bicuculline obtained using a fast Fourier transform algorithm. (From Khazipov and Holmes 2003; adapted, with permission, from the authors.) 
similar to that of IPSCs during whole-cell recordings from individual cells, and their decay slows down in the presence of diazepam. Similarly, activation of lacunosum-moleculare-or stratum oriens-projecting interneurons generate UIPSPs with the sources located in the regions in which the axon terminals of these interneurons are located. Extracellular feedback IPSCs also occur during spontaneous activity in CA3 hippocampal slices (Beyeler et al. 2013). They are preceded by mutual excitation of pyramidal cells via recurrent collaterals with further recruitment of inhibitory interneurons and powerful inhibition of multiple unit activity during a 10-msec time window that corresponds to the time course of the field IPSCs. Although single interneurons generate field potentials (active sources), single pyramidals do not generate detectable active sinks despite a much larger driving force for the excitatory synapses (glutamatergic currents reverse at or near $0 \mathrm{mV}$ and, therefore, the driving force acting on them is $\sim 80 \mathrm{mV}$ at resting conditions) (Bazelot et al. 2010; Oren et al. 2010). This difference is likely caused by more than a 10-fold higher density of GABAergic synapses compared with glutamatergic ones, 80 and 5 per $100 \mu \mathrm{m}^{3}$, respectively (Wittner and Miles 2007; Olah et al. 2009).

Outward currents through $\mathrm{GABA}_{\mathrm{A}}$ receptors may also participate in the generation of LFPs during network-driven activities. This is clearly the case of sources generated by the perisomatic projecting interneurons in the pyramidal cell layer during cholinergically or kainateinduced $\gamma$ oscillations in vitro and physiological $\gamma$ oscillations in vivo (Csicsvari et al. 2003; Mann et al. 2005; Gulyas et al. 2010; Oren et al. 2010), and epileptiform activities at $\gamma$ frequencies in vivo (Khazipov and Holmes 2003). Contributions of GABAergic signals to other epileptic EEG manifestations are less well understood, however. There are several factors that predict important GABAergic contributions to the extracellular field potential during seizure. Indeed, interneurons actively participate in paroxysmal discharges (Marchionni and Maccaferri 2009), and synchronous firing of multiple interneurons should result in a summation of their active sources. Second, neuronal depolarization during seizure increases the driving force for hyperpolarizing $D F_{\mathrm{GABA}}$; this may diminish and even inverse to depolarizing directions during seizure, however (FujiwaraTsukamoto et al. 2003; Isomura et al. 2008; Glykys et al. 2014). On the other hand, massive sinks and sources during epileptiform events generated by glutamatergic synaptic currents, voltage-gated sodium, calcium, and potassium currents may obscure these GABAergic contributions to the field potentials during full-blown seizure. GABAergic currents have been evidenced contributing to the generation of the repetitive active sources during high-frequency oscillations occurring in cortical slices in magnesium-free conditions during interictal events and the onset of seizures (Trevelyan 2009). These time periods are when pyramidal cell firing is vetoed by high-frequency volleys of inhibitory synaptic currents, thereby providing an inhibitory restraint that opposes epileptiform spread (Trevelyan and Schevon 2013). The visibility of the inhibitory currents in the field recordings was greatest when local pyramidal cell activity is suppressed and worsened when local activity increases, suggestive of a switch from one source of high-frequency oscillation to another as the restraint starts to fail.

\section{SYNCHRONIZATION OF EPILEPTIFORM ACTIVITIES BY EXCITATORY GABA}

Hyperpolarizing inhibitory actions of GABA discussed above are not ubiquitous. Under certain conditions and states, including early developmental stages and epilepsy, GABA may exert depolarizing actions (Ben-Ari et al. 2007; Blaesse et al. 2009; Pavlov et al. 2013). Depolarizing actions of GABA are primarily because of elevated intracellular chloride concentration that sets $E_{\mathrm{GABA}}$ at the values more positive than $E_{m}$. Elevated chloride maybe a "steady-state" characteristic determined by a specific set of chloride cotransporters and channels where chloride loading exceeds chloride extrusion (Payne et al. 2003). It can also occur in a transient manner as a result of chloride accumulation during hyperactivity (Fujiwara-Tsukamoto et al. 2003; Isomura et al. 2008; Glykys et al. 
2014). In addition, depolarizing actions of GABA may result from bicarbonate permeability of $\mathrm{GABA}_{\mathrm{A}}$ channels (Kaila et al. 1993; Staley et al. 1995) as well as from elevation of extracellular potassium caused by KCC2-mediated extrusion of chloride and potassium (Viitanen et al. 2010).

Depolarizing GABA actions associated with a steady-state elevated intracellular chloride are particularly well documented during development (Ben-Ari et al. 2007). Immature neurons are characterized by low levels of expression and function of potassium/chloride cotransporter KCC2, which is the main chloride extruder; but, on the other hand, they highly express chloride loader NKCC1 (Rivera et al. 1999; Yamada et al. 2004; Dzhala et al. 2005). As a result, intracellular chloride is set at high levels that explain the depolarizing action of GABA (and glycine) on the immature neurons with $D F_{\mathrm{GABA}}$ typically attaining values in the range of $10-30 \mathrm{mV}$ (Tyzio et al. 2007, 2008). This positive in direction, but limited in size, depolarizing action of GABA determines complex, often referred to as "dual" (both excitatory and inhibitory), actions of GABA on the immature neurons and complex roles of GABAergic interneurons in the developing networks during generation of the physiological and epileptic activity patterns.

Excitatory action implies that GABA triggers APs in the postsynaptic neurons. Although GABA does indeed often trigger APs in neonatal cortical neurons, these early excitatory actions of GABA have several particular features on the probability and timing of spikes evoked by depolarizing GABA. Direct short-latency excitatory actions of GABA during development are infrequent, because $E_{\mathrm{GABA}}$ is typically more negative than the AP threshold (Rheims et al. 2008; Valeeva et al. 2010). Instead, transmission of excitation at depolarizing GABAergic synapses is characterized by relatively low probability of postsynaptic spikes and their long and variable delays in the postsynaptic neurons. Thus, in the neonatal rat hippocampal slices, the delays of APs evoked by synaptic activation of $\mathrm{GABA}_{\mathrm{A}}$ receptors were found to be long (mean, $65 \mathrm{msec}$ ) and variable (within a time window of $10-200 \mathrm{msec}$ ) (Valeeva et al.
2010). Depolarizing GABAergic responses often remained subthreshold and their amplification by persistent sodium conductance was required to trigger APs; recruitment of this intermediate step explains long and variable delays of APs in the postsynaptic cell. Importantly, AP delays may be artificially shortened and their variability reduces with an increase in $\left[\mathrm{Cl}^{-}\right]_{\mathrm{i}}$ during whole-cell dialysis (Fig. 3). In addition to persistent sodium currents, depolarizing GABA also activates voltage-gated calcium channels, evokes calcium transients in the immature neurons (Garaschuk et al. 2000; Bonifazi et al. 2009), and attenuates voltage-dependent magnesium blockage of $N$-methyl-D-aspartate (NMDA) channels (Khazipov et al. 1997; Leinekugel et al. 1997). Depolarizing GABAergic responses facilitate APs evoked by subthreshold excitatory responses (mimicking fast $\alpha$-amino3-hydroxy-5-methyl-4-isoxazolepropionic acid (AMPA)-receptor-mediated EPSPs) if the latter are activated at the late phase of GABAergic depolarization, when the shunting effect of GABAergic conduction ceases (Chen et al. 1996). However, EPSPs are shunted during the time period when $\mathrm{GABA}_{\mathrm{A}}$ channels stay open clamping membrane potential near $E_{\mathrm{GABA}}$. Through this shunting mechanism, depolarizing GABA exerts its inhibitory actions. Similar complex interactions between depolarizing GABAergic and glutamatergic inputs have also been described in adult L5 neurons and granular cells (Staley and Mody 1992; Gulledge and Stuart 2003). In addition, GABAergic depolarization activates voltage-gated potassium channels, and causes an inactivation of voltage-gated sodium channels that decreases cell excitability, further contributing to the inhibitory actions of depolarizing GABA ( $\mathrm{Lu}$ and Trussell 2001; Monsivais and Rubel 2001).

Dualism in depolarizing GABA actions and slow spike timing at depolarizing GABAergic synapses are critical for the understanding of physiological and paroxysmal activities in the developing and epileptic networks. One of the best illustrations is an activity pattern of network-driven giant depolarizing potentials (GDPs) in the developing hippocampus. GDPs are recurrent network-driven bursts of 
GABAergic Synchronization in Epilepsy

A
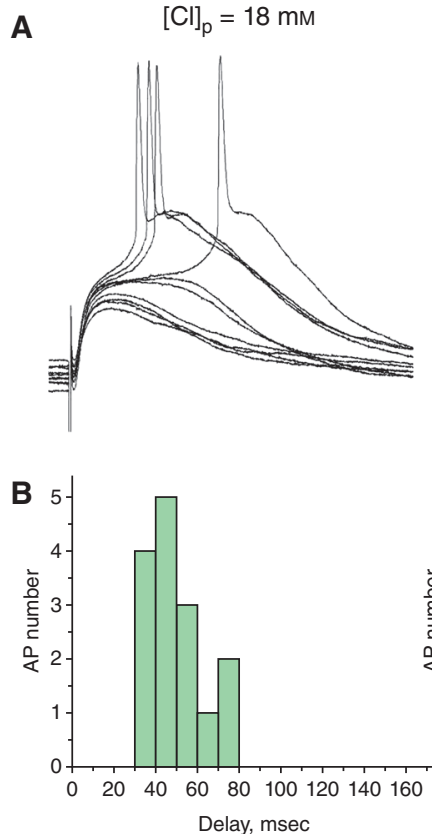
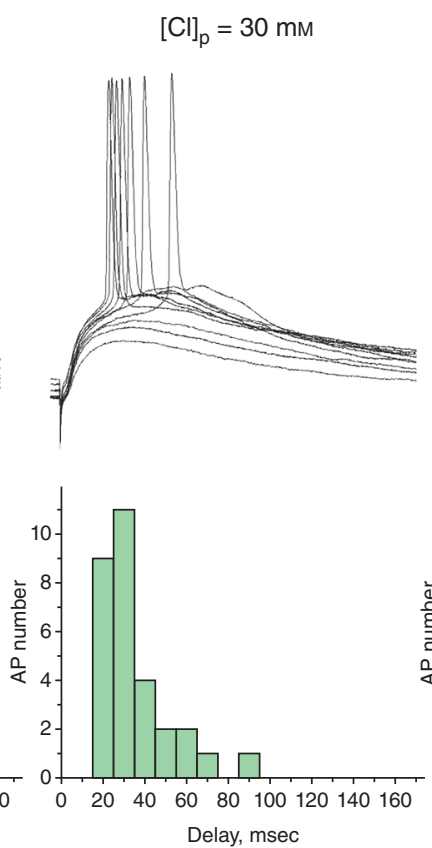

$[\mathrm{Cl}]_{\mathrm{p}}=140 \mathrm{~mm}$
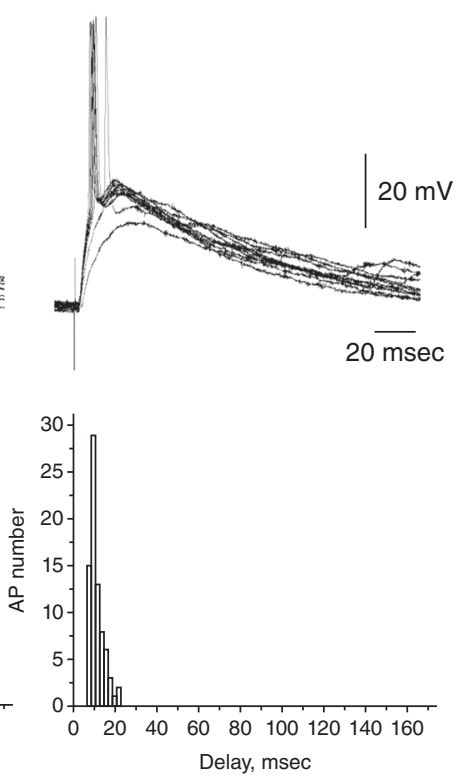

Figure 3. Spike probability and timing at depolarizing $\gamma$-aminobutyric acid (GABA)ergic synapses as a function of intracellular chloride concentration. $(A) \mathrm{GABA}_{\mathrm{A}}$ receptor-mediated postsynaptic potentials recorded from CA3 pyramidal cells in whole-cell current-clamp configuration at different $\left[\mathrm{Cl}^{-}\right]_{\mathrm{p}}$. GABA-PSPs (postsynaptic potentials) were evoked by electrical stimulation in the presence of the glutamate and $\mathrm{GABA}_{\mathrm{B}}$ receptors blockers. (B) Corresponding histograms of the GABA-PSP-triggered action potential (AP) delays. Note that, at $\left[\mathrm{Cl}^{-}\right]_{\mathrm{p}}=$ $18 \mathrm{~mm}$ (i.e., close to physiological $\left[\mathrm{Cl}^{-}\right]_{\mathrm{i}}$ in the immature neurons), probability of GABA-evoked APs is low and their delays are long and variable. Probability of evoking APs increase and their delays and variability decrease with an increase in $\left[\mathrm{Cl}^{-}\right]_{\mathrm{p}}$. (From Valeeva et al. 2010; reprinted, courtesy of an exclusive license agreement between the authors and the Frontiers Research Foundation, which permits unrestricted use, distribution, and reproduction in any medium.)

activity generated in the neonatal rat hippocampal slices and in the intact hippocampi in vitro (Ben-Ari et al. 1989). GDPs were initially described as purely GABAergic events driven by depolarizing GABA. However, recurrent glutamatergic synapses were found to play equally important roles in GDP generation, and excitation of pyramidal cells and interneurons is determined by summation of depolarizing GABA and glutamate-activated conductances and their interactions with the voltage-gated conductances (Khazipov et al. 1997; Leinekugel et al. 1997; Bolea et al. 1999; Sipila et al. 2006a). Low-probability and slow and variable excitation at GABAergic synapses determines a relatively low level of neuronal synchrony during generation and propagation of GDPs that may take several hundreds of milliseconds along the septotemporal axis (Leinekugel et al. 1998). Depolarizing and excitatory GABA actions are instrumental in GDP generation as a blockade of NKCC1 with bumetanide that reduces intracellular chloride and eliminates depolarizing $D F_{\mathrm{GABA}}$, which also completely suppresses GDPs (Dzhala et al. 2005; Sipila et al. 2006b; Nardou et al. 2009). At low doses, bumetanide reduces GDP frequency and slows down GDP propagation (Valeeva et al. 2010). Positive allosteric modulators of $\mathrm{GABA}_{\mathrm{A}}$ receptors diazepam increases GDP frequency but also desynchronizes neuronal synchronization during GDP and slows down their propagation (Khalilov et al. 1999; Valeeva et al. 2010). On the other hand, partial blockade of $\mathrm{GABA}_{\mathrm{A}}$ receptors increases neuronal synchronization and accelerates GDP propagation (Valeeva et al. 2010), 
whereas total suppression of $\mathrm{GABA}_{\mathrm{A}}$ receptor function transforms GDPs to supersynchronous and rapidly propagating epileptiform discharges-interictal-like events in hippocampal slices and tonic-clonic ictal-like events in the intact hippocampus preparation and in vivo (Baram and Snead 1990; Khalilov et al. 1997, 1999; Khazipov et al. 1997, 2001, 2004; Isaev et al. 2005; Kolbaev et al. 2012).

As indicated above, AP probability and delays at depolarizing GABAergic synapses are dependent on $\left[\mathrm{Cl}^{-}\right]_{i}$, and their probability increases, whereas the delays shorten and their variability reduces with an increase in $\left[\mathrm{Cl}^{-}\right]_{\mathrm{i}}$ (Fig. 3). From this observation, one may predict that an increase in $\left[\mathrm{Cl}^{-}\right]_{\mathrm{i}}$ will result in an increase in excitatory power of GABA manifested by higher AP probability, and by a reduction of AP delays and their variability at GABAergic synapses. Altogether, these changes should lead to an increase in neuronal synchronization and, thus, favor seizure. It is very unlikely that depolarizing $D F_{\mathrm{GABA}}$ can ever attain the values of $D F_{\text {glutamate }}$ (for that intracellular chloride should replace all organic anions in the cell) and, therefore, excitatory power of GABA will never reach that of glutamate. However, the balance between excitation and inhibition in dualistic actions of depolarizing GABA and associated synchronizing-desynchronizing effects of depolarizing GABA at the network level can shift toward excitatory and synchronizing with an increase in $\left[\mathrm{Cl}^{-}\right]_{\mathrm{i}}$.

This hypothesis is supported by a number of observations made not only in developing but also in adult brain. First, accumulation of $\left[\mathrm{Cl}^{-}\right]_{\mathrm{i}}$, which develops as a result of impairment in KCC2-mediated chloride extrusion or up-regulation of NKCC1-mediated chloride load, is associated with profound transformations in the network function and an emergence of the epileptiform events. Steady-state increase in $\left[\mathrm{Cl}^{-}\right]_{\mathrm{i}}$ and associated depolarizing shift in $E_{\mathrm{GABA}}$ develops during recurrent seizures in the "mirror-focus" model of epileptogenesis using interconnected hippocampi in vitro (Khalilov et al. 2003, 2005; Nardou et al. 2009), in a low-magnesium model in the intact hippocampus in vitro with a remarkable dependence of $\left[\mathrm{Cl}^{-}\right]_{\mathrm{i}}$ on the number of ictal-like episodes (Fig. 4B) (Dzhala et al. 2010). In human epileptic subiculum, recruitment of $\sim 20 \%$ neurons into interictal discharges is determined by a loss of KCC2 and depolarizing GABA actions in these cells (Cohen et al. 2002; Palma et al. 2006; Huberfeld et al. 2007). Similarly, accumulation of $\left[\mathrm{Cl}^{-}\right]_{\mathrm{i}}$ and an inversion of the GABA action from inhibitory to excitatory, which develops during seizure, supports population discharges both in the immature and adult brain (Fujiwara-Tsukamoto et al. 2003, 2010; Glykys et al. 2014).

Second, drugs enhancing GABAergic conductance exert desynchronizing and anticonvulsive actions at low or moderately elevated physiological levels of $\left[\mathrm{Cl}^{-}\right]_{\mathrm{i}}$; however, these are reduced, lost, or even inverted to synchronizing and proconvulsive actions during the states when $\left[\mathrm{Cl}^{-}\right]_{\mathrm{i}}$ is increased. For example, phenobarbital efficiently suppresses first seizures evoked by low-magnesium and propagating seizures in the interconnected hippocampi preparation, but it loses its anticonvulsive actions or even aggravates seizures after multiple seizures, along with an accumulation of $\left[\mathrm{Cl}^{-}\right]_{\mathrm{i}}$ and a progressive depolarizing shift in $E_{\mathrm{GABA}}$ in these two models (Fig. 4) (Dzhala et al. 2010; Nardou et al. 2011).

Third, restoration of physiological levels of $\left[\mathrm{Cl}^{-}\right]_{\mathrm{i}}$ (e.g., using NKCC1 antagonist bumetanide) in those cases when $\left[\mathrm{Cl}^{-}\right]_{\mathrm{i}}$ is pathologically elevated suppresses seizures and enhances anticonvulsant actions of the drugs enhancing GABAergic conductance. Bumetanide shows little anticonvulsive efficiency against the first seizure in various models (Dzhala et al. 2005, 2008, 2010; Kilb et al. 2007; Nardou et al. 2009; Minlebaev and Khazipov 2011). However, following multiple seizures that lead to accumulation of $\left[\mathrm{Cl}^{-}\right]_{\mathrm{i}}$ as well as in human epileptic cortex characterized by elevated $\left[\mathrm{Cl}^{-}\right]_{\mathrm{i}}$ in a proportion of neurons, bumetanide exerts powerful anticonvulsive effects and potentiates anticonvulsive actions of drugs enhancing $\mathrm{GABA}_{\mathrm{A}}$ receptor conductance (Fig. 5) (Huberfeld et al. 2007; Dzhala et al. 2008, 2010; Nardou et al. 2009, 2011). Thus, correction of chloride homeostasis could be one of strategies to cure epilepsies that are mechanistically linked to ele- 


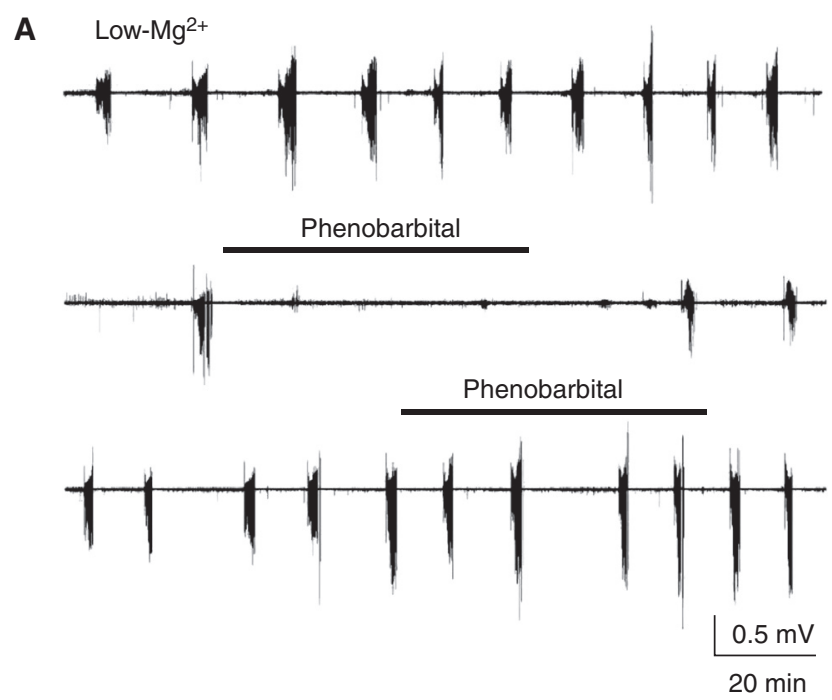

B

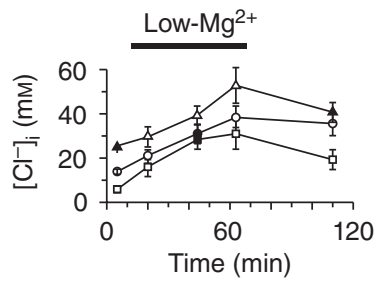

C

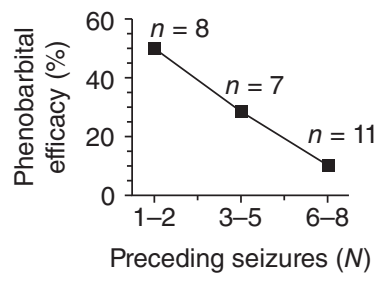

Figure 4. Seizure-dependent changes in the effects of phenobarbital on neonatal seizures. $(A)$ Low- $\mathrm{Mg}^{2+}$ artificial cerebrospinal fluid (ACSF)-induced recurrent seizures in the intact hippocampus in vitro (top trace). Application of phenobarbital $(100 \mu \mathrm{M})$ in low- $\mathrm{Mg}^{2+}$ ACSF after one ictal-like event $(N=1$, middle trace) abolished seizures in the intact neonatal hippocampus. Application of phenobarbital $(100 \mu \mathrm{M})$ after five ictallike events $\left(N=5\right.$, bottom trace) failed to abolish recurrent ictal-like activity in low- $\mathrm{Mg}^{2+}$ ACSF. Extracellular field potential recordings were performed in the CA3 pyramidal cell layer in the intact hippocampus in vitro of neonatal $(\mathrm{P} 5-6)$ rats. $(B)$ Changes of mean $[\mathrm{Cl}]_{\mathrm{i}}$ in subpopulation of neurons with a low $(0-10 \mathrm{~mm})$, medium $(10-20 \mathrm{~mm})$, and high $(20-30 \mathrm{~mm})$ range of control resting chloride measured using biphoton imaging of $[\mathrm{Cl}]_{\mathrm{i}}$ in chlomeleon CLM-1 mice. $(C)$ Fraction of hippocampi in low- $\mathrm{Mg}^{2+} \mathrm{ACSF}$, in which seizures were abolished by $100 \mu \mathrm{m}$ phenobarbital, plotted as a function of the number of seizures before phenobarbital application. Efficacy of phenobarbital in neonatal seizures decreased as a function of quantity of prior seizure activity $(N)$. (Panels from Dzhala et al. 2010; reprinted, with permission, from the Society for Neuroscience (C)2010.)

vated $\left[\mathrm{Cl}^{-}\right]_{\mathrm{i}}$. Evidence on the anticonvulsive effects of bumetanide is mainly limited to in vitro models, however, probably because the drug heavily binds to plasma proteins and poorly crosses the blood-brain barrier (Javaheri et al. 1993; Loscher et al. 2013). To overcome these problems, lipophilic and uncharged prodrugs of bumetanide that penetrate the blood-brain barrier more easily than the parent drug and are converted into bumetanide in the brain have been developed and, one such compound, $\mathrm{N}, \mathrm{N}$-dimethylaminoethylester (BUM5), but not bumetanide, counteracted the alteration in seizure threshold during the latent period of the pilocarpine model in mice. In the kindling model in rats, BUM5 was more efficacious than bumetanide in potentiating the anticonvulsant effect of phenobarbital (Tollner et al. 2014).

\section{CONCLUDING REMARKS}

Examples of the epileptiform activity synchronized by hyperpolarizing and depolarizing GABA presented in this review indicate that, 


\section{R. Khazipov}

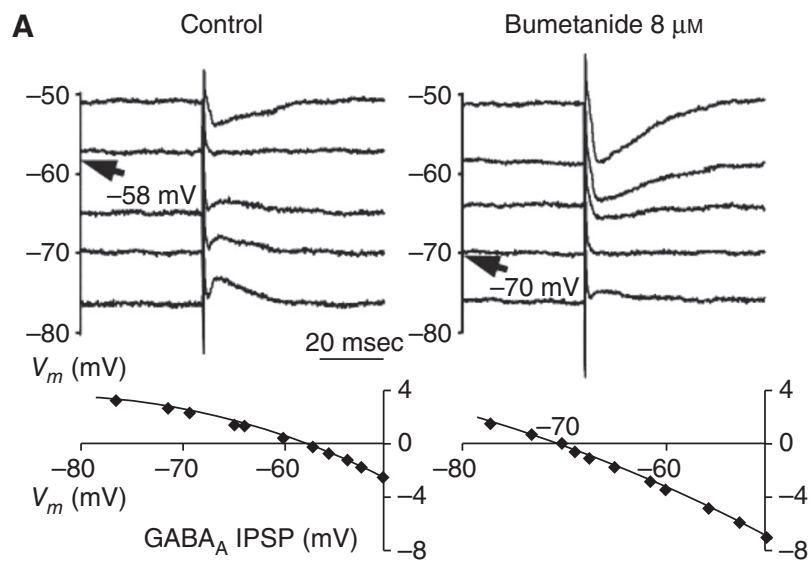

B
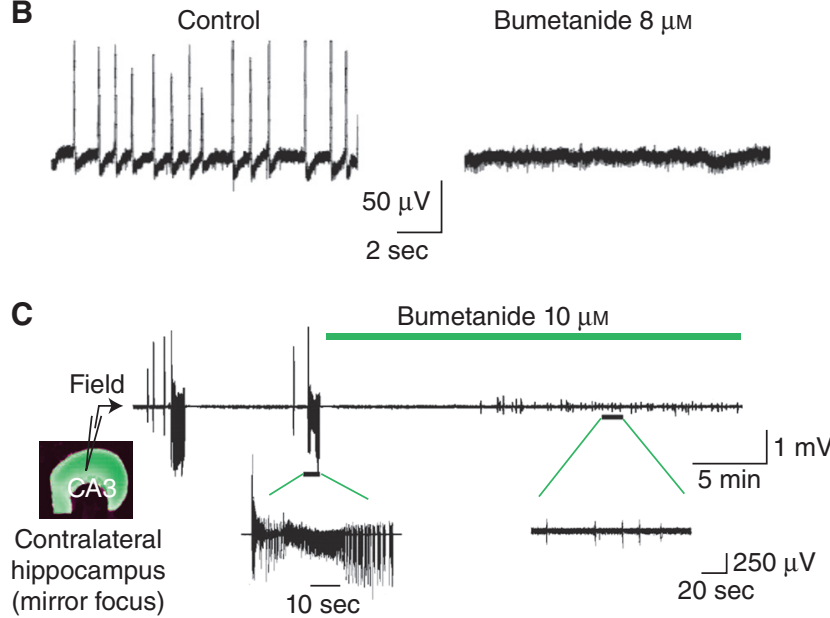

Figure 5. Effects of NKCC1 antagonist bumetanide in epileptic cortex. (A) Bumetanide ( $8 \mu \mathrm{M})$ hyperpolarized the reversal potential of $\gamma$-amino butyric acid (GABA)ergic inhibitory postsynaptic potentials (IPSPs) in slices of human epileptic subiculum. Top traces show synaptic events at different membrane potentials $\left(V_{m}\right)$. Reversal potentials are indicated with an arrow. Bottom traces plot IPSP amplitude against membrane potential. $(B)$ Bumetanide blocked spontaneous epileptiform bursts in human subiculum. Traces show that extracellular interictal-like field potentials (left) are blocked by bumetanide (right). (C) Bumetanide blocked ictal-like field potentials in the "mirror-focus" rat hippocampus. (Panels A and B from Huberfeld et al. 2007; reprinted, with permission, from the Society for Neuroscience (C) 2007. Panel C from Nardou et al. 2009; reprinted, with permission, from The American Physiological Society (C) 2009.)

under certain conditions, GABA may act as a network synchronizer promoting seizure. A common feature in both cases consists of GABAergic control of spike timing in the postsynaptic neurons, which is achieved via synchronous rebound firing in the case of hyperpolarizing GABA and synchronous excitation in the case of depolarizing GABA. Synchronizing power of depolarizing GABA is strongly de- pendent on $\left[\mathrm{Cl}^{-}\right]_{\mathrm{i}}$, and restoration of physiological chloride gradients may be beneficial in epilepsies associated with altered chloride homeostasis.

\section{ACKNOWLEDGMENTS}

Financial support from Agence Nationale de la Recherche (ANR) (Grant ANR-09-MNPS-006), 
the Government of the Russian Federation (Grant 11.G34.31.0075 and the Program of Competitive Growth of Kazan University), and Fondation pour la Recherche Medicale (FRM) (DEQ20110421301) is acknowledged.

\section{REFERENCES}

Baram TZ, Snead OC. 1990. Bicuculline induced seizures in infant rats: Ontogeny of behavioral and electrocortical phenomena. Dev Brain Res 57: 291-295.

Bazelot M, Dinocourt C, Cohen I, Miles R. 2010. Unitary inhibitory field potentials in the CA3 region of rat hippocampus. J Physiol 588: 2077-2090.

Ben-Ari Y, Cherubini E, Corradetti R, Gaïarsa JL. 1989. Giant synaptic potentials in immature rat CA3 hippocampal neurones. J Physiol 416: 303-325.

Ben-Ari Y, Gaiarsa JL, Tyzio R, Khazipov R. 2007. GABA: A pioneer transmitter that excites immature neurons and generates primitive oscillations. Physiol Rev 87: $1215-$ 1284.

Beyeler A, Retailleau A, Molter C, Mehidi A, Szabadics J, Leinekugel X. 2013. Recruitment of perisomatic inhibition during spontaneous hippocampal activity. PLoS ONE 8: e66509.

Blaesse P, Airaksinen MS, Rivera C, Kaila K. 2009. Cationchloride cotransporters and neuronal function. Neuron 61: $820-838$.

Bolea S, Avignone E, Berretta N, Sanchez-Andres JV, Cherubini E. 1999. Glutamate controls the induction of GABA-mediated giant depolarizing potentials through AMPA receptors in neonatal rat hippocampal slices. $J$ Neurophysiol 81: 2095-2102.

Bonifazi P, Goldin M, Picardo MA, Jorquera I, Cattani A, Bianconi G, Represa A, Ben-Ari Y, Cossart R. 2009. GABAergic hub neurons orchestrate synchrony in developing hippocampal networks. Science 326: 1419-1424.

Buzsaki G. 2006. Rhythms of the brain. Oxford University Press, New York.

Chen G, Trombley PQ, van den Pol AN. 1996. Excitatory actions of GABA in developing rat hypothalamic neurones. J Physiol 494: 451-464.

Cohen I, Navarro V, Clemenceau S, Baulac M, Miles R. 2002. On the origin of interictal activity in human temporal lobe epilepsy in vitro. Science 298: 1418-1421.

Connors BW. 1984. Initiation of synchronized neuronal bursting in neocortex. Nature 310: 685-687.

Csicsvari J, Jamieson B, Wise KD, Buzsaki G. 2003. Mechanisms of $\gamma$ oscillations in the hippocampus of the behaving rat. Neuron 37: 311-322.

Curtis DR, Felix D, McLellan H. 1970. GABA and hippocampal inhibition. Br J Pharmacol 40: 881-883.

Dzhala VI, Talos DM, Sdrulla DA, Brumback AC, Mathews GC, Benke TA, Delpire E, Jensen FE, Staley KJ. 2005. NKCC1 transporter facilitates seizures in the developing brain. Nat Med 11: 1205-1213.

Dzhala VI, Brumback AC, Staley KJ. 2008. Bumetanide enhances phenobarbital efficacy in a neonatal seizure model. Ann Neurol 63: 222-235.
Dzhala VI, Kuchibhotla KV, Glykys JC, Kahle KT, Swiercz WB, Feng G, Kuner T, Augustine GJ, Bacskai BJ, Staley KJ. 2010. Progressive NKCC1-dependent neuronal chloride accumulation during neonatal seizures. J Neurosci 30: $11745-11761$.

Freund T, Buzsaki G. 1996. Interneurons of the hippocampus. Hippocampus 6: 345-470.

Fujiwara-Tsukamoto Y, Isomura Y, Nambu A, Takada M. 2003. Excitatory GABA input directly drives seizure-like rhythmic synchronization in mature hippocampal CA1 pyramidal cells. Neuroscience 119: 265-275.

Fujiwara-Tsukamoto $Y$, Isomura $Y$, Imanishi M, Ninomiya T, Tsukada M, Yanagawa Y, Fukai T, Takada M. 2010. Prototypic seizure activity driven by mature hippocampal fast-spiking interneurons. J Neurosci 30: 13679-13689.

Garaschuk O, Linn J, Eilers J, Konnerth A. 2000. Large-scale oscillatory calcium waves in the immature cortex. Nat Neurosci 3: 452-459.

Glickfeld LL, Roberts JD, Somogyi P, Scanziani M. 2009. Interneurons hyperpolarize pyramidal cells along their entire somatodendritic axis. Nat Neurosci 12: 21-23.

Glykys J, Dzhala V, Egawa K, Balena T, Saponjian Y, Kuchibhotla KV, Bacskai BJ, Kahle KT, Zeuthen T, Staley KJ. 2014. Local impermeant anions establish the neuronal chloride concentration. Science 343: 670-675.

Gulledge AT, Stuart GJ. 2003. Excitatory actions of GABA in the cortex. Neuron 37: 299-309.

Gulyas AI, Szabo GG, Ulbert I, Holderith N, Monyer H, Erdelyi F, Szabo G, Freund TF, Hajos N. 2010. Parvalbumin-containing fast-spiking basket cells generate the field potential oscillations induced by cholinergic receptor activation in the hippocampus. J Neurosci 30: 1513415145 .

Huberfeld G, Wittner L, Clemenceau S, Baulac M, Kaila K, Miles R, Rivera C. 2007. Perturbed chloride homeostasis and GABAergic signaling in human temporal lobe epilepsy. J Neurosci 27: 9866-9873.

Isaev D, Isaeva E, Khazipov R, Holmes GL. 2005. Anticonvulsant action of GABA in the high potassium-low magnesium model of ictogenesis in the neonatal rat hippocampus in vivo and in vitro. J Neurophysiol 94: 29872992.

Isomura Y, Fujiwara-Tsukamoto Y, Takada M. 2008. A network mechanism underlying hippocampal seizure-like synchronous oscillations. Neurosci Res 61: 227-233.

Javaheri S, Davis C, Rogers DH. 1993. Ionic composition of cisternal CSF in acute respiratory acidosis: Lack of effect of large dose bumetanide. J Neurochem 61: 1525-1529.

Kaila K, Voipio J, Paalasmaa P, Pasternack M, Deisz RA. 1993. The role of bicarbonate in $\mathrm{GABA}_{\mathrm{A}}$ receptor-mediated IPSPs of rat neocortical neurones. $J$ Physiol 464: 273-289.

Khalilov I, Khazipov R, Esclapez M, Ben-Ari Y. 1997. Bicuculline induces ictal seizures in the intact hippocampus recorded in vitro. Eur J Pharmacol 319: R5-R6.

Khalilov I, Dzhala V, Ben-Ari Y, Khazipov R. 1999. Dual role of GABA in the neonatal rat hippocampus. Dev Neurosci 21: $310-319$.

Khalilov I, Holmes GL, Ben-Ari Y. 2003. In vitro formation of a secondary epileptogenic mirror focus by interhippo- 
R. Khazipov

campal propagation of seizures. Nat Neurosci 6: 10791085.

Khalilov I, Le Van QM, Gozlan H, Ben-Ari Y. 2005. Epileptogenic actions of GABA and fast oscillations in the developing hippocampus. Neuron 48: 787-796.

Khazipov R, Holmes GL. 2003. Synchronization of kainateinduced epileptic activity via GABAergic inhibition in the superfused rat hippocampus in vivo. J Neurosci 23: 5337-5341.

Khazipov R, Leinekugel X, Khalilov I, Gaïarsa J-L, Ben-Ari Y 1997. Synchronization of GABAergic interneuronal network in CA3 subfield of neonatal rat hippocampal slices. $J$ Physiol 498: 763-772.

Khazipov R, Esclapez M, Caillard O, Bernard C, Khalilov I, Tyzio R, Hirsch J, Dzhala V, Berger B, Ben-Ari Y. 2001 Early development of neuronal activity in the primate hippocampus in utero. J Neurosci 21: 9770-9781.

Khazipov R, Khalilov I, Tyzio R, Morozova E, Ben-Ari Y, Holmes GL. 2004. Developmental changes in GABAergic actions and seizure susceptibility in the rat hippocampus. Eur J Neurosci 19: 590-600.

Kilb W, Sinning A, Luhmann HJ. 2007. Model-specific effects of bumetanide on epileptiform activity in the in vitro intact hippocampus of the newborn mouse. Neuropharmacology 53: 524-533.

Klaassen A, Glykys J, Maguire J, Labarca C, Mody I, Boulter J. 2006. Seizures and enhanced cortical GABAergic inhibition in two mouse models of human autosomal-dominant nocturnal frontal lobe epilepsy. Proc Natl Acad Sci 103: $19152-19157$.

Klausberger T, Somogyi P. 2008. Neuronal diversity and temporal dynamics: The unity of hippocampal circuit operations. Science 321: 53-57.

Kolbaev SN, Sharopov S, Dierkes PW, Luhmann HJ, Kilb W. 2012. Phasic $\mathrm{GABA}_{\mathrm{A}}$-receptor activation is required to suppress epileptiform activity in the CA3 region of the immature rat hippocampus. Epilepsia 53: 888-896.

Leinekugel X, Medina I, Khalilov I, Ben-Ari Y, Khazipov R. 1997. $\mathrm{Ca}^{2+}$ oscillations mediated by the synergistic excitatory actions of $\mathrm{GABA}_{\mathrm{A}}$ and NMDA receptors in the neonatal hippocampus. Neuron 18: 243-255.

Leinekugel X, Khalilov I, Ben-Ari Y, Khazipov R. 1998. Giant depolarizing potentials: The septal pole of the hippocampus paces the activity of the developing intact septohippocampal complex in vitro. J Neurosci 18: 6349-6357.

Lerche H, Shah M, Beck H, Noebels J, Johnston D, Vincent A. 2013. Ion channels in genetic and acquired forms of epilepsy. J Physiol 591: 753-764.

Loscher W, Puskarjov M, Kaila K. 2013. Cation-chloride cotransporters NKCC1 and KCC2 as potential targets for novel antiepileptic and antiepileptogenic treatments. Neuropharmacology 69: 62-74.

Lu T, Trussell LO. 2001. Mixed excitatory and inhibitory GABA-mediated transmission in chick cochlear nucleus. J Physiol 535: 125-131.

Mann EO, Paulsen O. 2007. Role of GABAergic inhibition in hippocampal network oscillations. Trends Neurosci 30: 343-349.

Mann EO, Suckling JM, Hajos N, Greenfield SA, Paulsen O. 2005. Perisomatic feedback inhibition underlies cholin- ergically induced fast network oscillations in the rat hippocampus in vitro. Neuron 45: 105-117.

Marchionni I, Maccaferri G. 2009. Quantitative dynamics and spatial profile of perisomatic GABAergic input during epileptiform synchronization in the CA1 hippocampus. J Physiol 587: 5691-5708.

Miles R, Wong RKS. 1987. Inhibitory control of local excitatory circuits in the guinea-pig hippocampus. J Physiol 388: $611-629$.

Minlebaev M, Khazipov R. 2011. Antiepileptic effects of endogenous $\beta$-hydroxybutyrate in suckling infant rats. Epilepsy Res 95: 100-109.

Monsivais P, Rubel EW. 2001. Accommodation enhances depolarizing inhibition in central neurons. J Neurosci 21: 7823-7830.

Nardou R, Ben-Ari Y, Khalilov I. 2009. Bumetanide, an NKCC1 antagonist, does not prevent formation of epileptogenic focus but blocks epileptic focus seizures in immature rat hippocampus. J Neurophysiol 101: $2878-$ 2888.

Nardou R, Yamamoto S, Chazal G, Bhar A, Ferrand N, Dulac O, Ben-Ari Y, Khalilov I. 2011. Neuronal chloride accumulation and excitatory GABA underlie aggravation of neonatal epileptiform activities by phenobarbital. Brain 134: $987-1002$.

Olah S, Fule M, Komlosi G, Varga C, Baldi R, Barzo P, Tamas G. 2009. Regulation of cortical microcircuits by unitary GABA-mediated volume transmission. Nature 461: 1278-1281.

Oren I, Hajos N, Paulsen O. 2010. Identification of the current generator underlying cholinergically induced $\gamma$ frequency field potential oscillations in the hippocampal CA3 region. J Physiol 588: 785-797.

Palma E, Amici M, Sobrero F, Spinelli G, Di AS, Ragozzino D, Mascia A, Scoppetta C, Esposito V, Miledi R, et al. 2006. Anomalous levels of Cl-transporters in the hippocampal subiculum from temporal lobe epilepsy patients make GABA excitatory. Proc Natl Acad Sci 103: 84658468.

Pavlov I, Kaila K, Kullmann DM, Miles R. 2013. Cortical inhibition, $\mathrm{pH}$ and cell excitability in epilepsy: What are optimal targets for antiepileptic interventions? J Physiol 591: 765-774.

Payne JA, Rivera C, Voipio J, Kaila K. 2003. Cation-chloride co-transporters in neuronal communication, development and trauma. Trends Neurosci 26: 199-206.

Rheims S, Minlebaev M, Ivanov A, Represa A, Khazipov R Holmes GL, Ben-Ari Y, Zilberter Y. 2008. Excitatory GABA in rodent developing neocortex in vitro. J Neurophysiol 100: 609-619.

Rivera C, Voipio J, Payne JA, Ruusuvuori E, Lahtinen H, Lamsa K, Pirvola U, Saarma M, Kaila K. 1999. The K ${ }^{+} /$ $\mathrm{Cl}^{-}$co-transporter KCC2 renders GABA hyperpolarizing during neuronal maturation. Nature 397: 251-255.

Sipila ST, Huttu K, Voipio J, Kaila K. 2006a. Intrinsic bursting of immature CA3 pyramidal neurons and consequent giant depolarizing potentials are driven by a persistent $\mathrm{Na}$ current and terminated by a slow Ca-activated K current. Eur J Neurosci 23: 2330-2338.

Sipila ST, Schuchmann S, Voipio J, Yamada J, Kaila K. 2006b. The Na-K-Cl cotransporter (NKCC1) promotes sharp 
GABAergic Synchronization in Epilepsy

waves in the neonatal rat hippocampus. J Physiol 573: 765-773.

Staley KJ, Mody I. 1992. Shunting of excitatory input to dentate gyrus granule cells by a depolarizing $\mathrm{GABA}_{\mathrm{A}}$ receptor-mediated postsynaptic conductance. J Neurophysiol 68: 197-212.

Staley KJ, Soldo BL, Proctor WR. 1995. Ionic mechanisms of neuronal excitation by inhibitory $\mathrm{GABA}_{\mathrm{A}}$ receptors. Science 269: 977-981.

Steriade M, McCormick DA, Sejnowski TJ. 1993. Thalamocortical oscillations in the sleeping and aroused brain. Science 262: 679-685.

Tollner K, Brandt C, Topfer M, Brunhofer G, Erker T, Gabriel M, Feit PW, Lindfors J, Kaila K, Loscher W. 2014. A novel prodrug-based strategy to increase effects of bumetanide in epilepsy. Ann Neurol 75: 550-562.

Trevelyan AJ. 2009. The direct relationship between inhibitory currents and local field potentials. J Neurosci 29: 15299-15307.

Trevelyan AJ, Schevon CA. 2013. How inhibition influences seizure propagation. Neuropharmacology 69: 45-54.

Tyzio R, Holmes GL, Ben-Ari Y, Khazipov R. 2007. Timing of the developmental switch in $\mathrm{GABA}_{\mathrm{A}}$ mediated signalling from excitation to inhibition in CA3 rat hippocampus using gramicidin perforated patch and extracellular recordings. Epilepsia 48: 96-105.
Tyzio R, Minlebaev M, Rheims S, Ivanov A, Jorquera I Holmes GL, Zilberter Y, Ben-Ari Y, Khazipov R. 2008. Postnatal changes in somatic $\gamma$-aminobutyric acid signalling in the rat hippocampus. Eur J Neurosci 27: 25152528.

Valeeva G, Abdullin A, Tyzio R, Skorinkin A, Nikolski E, Ben-Ari Y, Khazipov R. 2010. Temporal coding at the immature depolarizing GABAergic synapse. Front Cell Neurosci 4.

Viitanen T, Ruusuvuori E, Kaila K, Voipio J. 2010. The $\mathrm{K}^{+}-\mathrm{Cl}^{-}$cotransporter $\mathrm{KCC} 2$ promotes GABAergic excitation in the mature rat hippocampus. J Physiol 588: 1527-1540.

von Krosigk M, Bal T, McCormick DA. 1993. Cellular mechanisms of a synchronized oscillation in the thalamus. Science 261: 361-364.

Whittington MA, Cunningham MO, LeBeau FE, Racca C, Traub RD. 2011. Multiple origins of the cortical $\gamma$ rhythm. Dev Neurobiol 71: 92-106.

Wittner L, Miles R. 2007. Factors defining a pacemaker region for synchrony in the hippocampus. J Physiol 584: 867-883.

Yamada J, Okabe A, Toyoda H, Kilb W, Luhmann HJ, Fukuda A. 2004. Cl-uptake promoting depolarizing GABA actions in immature rat neocortical neurones is mediated by NKCC1. J Physiol 557: 829-841. 


\section{$\&_{\mathrm{CSH}}^{\infty} \&$ Cold Spring Harbor

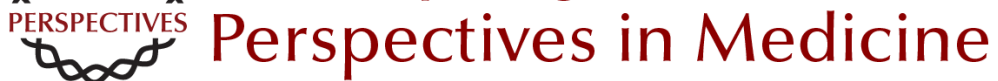

\section{GABAergic Synchronization in Epilepsy}

Roustem Khazipov

Cold Spring Harb Perspect Med 2016; doi: 10.1101/cshperspect.a022764 originally published online January 8, 2016

\section{Subject Collection Epilepsy: The Biology of a Spectrum Disorder}

The Epilepsy Spectrum: Targeting Future Research Challenges

Gregory L. Holmes and Jeffrey L. Noebels

Role of Sodium Channels in Epilepsy

David I. Kaplan, Lori L. Isom and Steven Petrou

\section{Mechanisms of Action of Antiseizure Drugs and the Ketogenic Diet \\ Michael A. Rogawski, Wolfgang Löscher and Jong M. Rho}

Epilepsy and Autism

Ashura W. Buckley and Gregory L. Holmes

Immunity and Inflammation in Epilepsy Annamaria Vezzani, Bethan Lang and Eleonora Aronica

Hyperpolarization-Activated Cyclic

Nucleotide-Gated (HCN) Channels in Epilepsy Gary P. Brennan, Tallie Z. Baram and Nicholas P. Poolos

The Role of Calcium Channels in Epilepsy Sanjeev Rajakulendran and Michael G. Hanna

Interneuron Transplantation as a Treatment for Epilepsy

Robert F. Hunt and Scott C. Baraban
Common Mechanisms Underlying

Epileptogenesis and the Comorbidities of

Epilepsy

Andrey Mazarati and Raman Sankar

The Diathesis-Epilepsy Model: How Past Events Impact the Development of Epilepsy and

Comorbidities

Christophe Bernard

Potassium Channels in Epilepsy

Rüdiger Köhling and Jakob Wolfart

GABAergic Synchronization in Epilepsy Roustem Khazipov

Status Epilepticus

Syndi Seinfeld, Howard P. Goodkin and Shlomo Shinnar

Neonatal and Infantile Epilepsy: Acquired and

Genetic Models Aristea S. Galanopoulou and Solomon L. Moshé

Epigenetics and Epilepsy

David C. Henshall and Katja Kobow

Microcircuits in Epilepsy: Heterogeneity and Hub Cells in Network Synchronization

Anh Bui, Hannah K. Kim, Mattia Maroso, et al.

For additional articles in this collection, see http://perspectivesinmedicine.cshlp.org/cgi/collection/ 